\title{
Accelerated ageing test to evaluate vigour in Jatropha curcas L. seeds $^{1}$
}

\author{
Teste de envelhecimento acelerado para avaliação do vigor de sementes de Jatropha \\ curcas L.
}

\author{
Glauter Lima Oliveira ${ }^{2 *}$, Luiz Antônio dos Santos Dias³, Denise Cunha Fernandes dos Santos Dias², Marcos \\ Morais Soares ${ }^{2}$ e Laércio Junio da Silva ${ }^{2}$
}

\begin{abstract}
There is currently great interest in the cultivation of the Jatropha curcas L., known locally as physic nut, for the production of biodiesel, leading to an increase in the demand for seeds and precise information as to their physiological quality, especially vigour. The objective was to evaluate the efficiency of the accelerated ageing test, with variations, in verifying the vigour of Jatropha seeds. Four seed lots were initially characterized as to their physiological quality by germination and vigour tests. For accelerated ageing test, temperatures of 42 and $45^{\circ} \mathrm{C}$ were tested during 48 , 72 and 96 hours. The experiment was carried out in a completely randomized design and the averages of the treatments compared by Tukey test $(\mathrm{p}<0,05)$. The Pearson correlation coefficients for the results of accelerated ageing against results from the other tests were calculated. The accelerated ageing test at 42 or $45{ }^{\circ} \mathrm{C}$ for 48 hours is efficient to classify Jatropha seed lots according to vigour level.
\end{abstract}

Key words: Physiological quality. Germination. Physic nut.

\begin{abstract}
RESUMO - Atualmente, há grande interesse pelo cultivo do pinhão manso para a produção de biodiesel, o que tem levado a um aumento na procura por sementes, exigindo informações precisas sobre a sua qualidade fisiológica, especialmente o vigor. Objetivou-se avaliar a eficiência do teste de envelhecimento acelerado, com variações, para a verificação do vigor de sementes de pinhão manso. Sementes de quatro lotes foram incialmente caracterizadas quanto à qualidade fisiológica pelos testes de germinação e de vigor. Para a realização do teste de envelhecimento acelerado, foram testadas as temperaturas de 42 e $45{ }^{\circ} \mathrm{C}$, por 48; 72 e 96 horas. O experimento foi conduzido em delineamento inteiramente casualizado e as médias dos tratamentos comparadas pelo teste de Tukey $(\mathrm{p}<0,05)$. Foram calculados os coeficientes de correlação de Pearson entre os resultados de envelhecimento acelerado e os dos demais testes. O teste de envelhecimento acelerado a 42 ou $45{ }^{\circ} \mathrm{C}$ por 48 horas, é eficiente para classificar lotes de sementes de pinhão manso em níveis de vigor.
\end{abstract}

Palavras-chave: Qualidade fisiológica. Germinação. Pinhão manso.

\footnotetext{
*Autor para correspondência

${ }^{1}$ Recebido para publicação em 08/08/2012; aprovado em 08/10/2013

Parte dos dados da Dissertação de Mestrado do primeiro autor defendida na Universidade Federal de Viçosa-MG

${ }^{2}$ Universidade Federal de Viçosa, Viçosa-MG, Brasil, glauteragro@hotmail.com, dcdias@ufv.br, agromms@yahoo.com.br, laerciojdsilva@ gmail.com

${ }^{3}$ Departamento de Fitotecnia, Universidade Federal de Viçosa, Av. PH Rolfs s/n, Campus Universitário, Viçosa-MG, 36.570-000, Brasil, lasdias@ufv.br
} 


\section{INTRODUCTION}

Interest in the cultivation of the Jatropha, known as physic nut, used in the production of biodiesel, has resulted in an increased demand for seeds. However, for the secure marketing of lots of this species, information is required on the quality of the seeds, especially vigour, which is related to performance both in the field and in storage.

Seed vigour includes those properties that determine potential for emergence and the rapid and uniform development of seedlings in a wide variety of environments. The basic objectives of the vigour tests are the identification of differences in the physiological potential of seed lots of similar germination, complementing the information provided by the germination test, and classifying lots with different levels of vigour in a similar manner to the emergence of seedlings in the field (MARCOS FILHO, 1999).

Among the vigour tests most used today is that of accelerated ageing, which allows estimating the longevity of seeds in storage and identifying differences in the physiological quality of lots with a similar capacity for germination by subjecting the seeds to high temperatures and relative humidity. In this test, the interaction between temperature and ageing period is important for the efficient evaluation of vigour, but for many species this has not yet been well established, as Jatropha. The interaction varies according to species, there being indications of success with the use of temperatures of between 40 and $45^{\circ} \mathrm{C}$, and periods of ageing from 48 to 96 hours (MARCOS FILHO, 1999).

The accelerated ageing test has been used to assess the vigour of Jatropha seeds in researches on maturation (SILVA et al., 2012), drying (ZONTA et al., 2011) and storage (PEREIRA, 2011), despite the methodology for this species not yet being fully established. In seeds of the castor bean, accelerated ageing at $40{ }^{\circ} \mathrm{C}$ for 48 hours at $76 \% \mathrm{RH}$ was the most efficient method of classifying lots by levels of vigour, while a 72-hour period caused the death of the seeds (ROCHA et al., 2007), also certified by Braga Júnior et al. (2011). Whereas for Mendes et al. (2010), the accelerated ageing test at $41{ }^{\circ} \mathrm{C}$ and $100 \% \mathrm{RH}$ for 72 hours, was effective in identifying the level of vigour in castor bean seeds, enabling a similar classification of lots to that obtained with the test of emergence in the soil. These authors also found that the test conducted at $45^{\circ} \mathrm{C}$ and $100 \%$ $\mathrm{RH}$ for 48,72 and 96 hours, caused excessive deterioration of the seeds, making it difficult to identify the real level of vigour of the lots. More recently, Braga Júnior et al. (2011) evaluated the effectiveness of the accelerated ageing test, using both the traditional method (100\% RH) and the modified method with a saturated $\mathrm{NaCl}$ solution $(75 \% \mathrm{RH})$ at $40{ }^{\circ} \mathrm{C}$ for 24,48 and 72 hours, finding that the modified method at $40{ }^{\circ} \mathrm{C}$ for 24 and 48 hours was most suitable for the separation of lots of castor bean as to vigour.

Consistent results were also obtained using seeds of the peanut at a temperature of $42{ }^{\circ} \mathrm{C}$ for 72 hours (ROSSETTO; LIMA; GUIMARÃES, 2004; ROSSETTO; ARAÚJO; LIMA, 2003).

The aim of this work was to adapt the methodology of the accelerated ageing test in order to evaluate the vigour of Jatropha seeds.

\section{MATERIAL AND METHODS}

The research was carried out at the Seed Laboratory of the Department of Plant Science at the Federal University of Viçosa in Minas Gerais, Brazil. Four seed lots of Jatropha were used, obtained from NNE Agroflorestal, located in the town of Janaúba in Minas Gerais State, Brazil.

The seeds were treated with the fungicide Derosal Plus ${ }^{\circledR}$ in the proportion of $6 \mathrm{~mL} 100^{-1} \mathrm{~kg}$ of seed, and then placed into bags of Kraft paper and stored in a cold room $\left(10 \pm 2{ }^{\circ} \mathrm{C}\right.$ at $\left.50 \% \mathrm{RH}\right)$ throughout the experimental period.

For the accelerated ageing test the methodology described by Marcos Filho (1999) was employed. A single layer of seeds from each lot was placed on a wire mesh in a plastic gerbox containing $40 \mathrm{~mL}$ of water at the bottom. The boxes were covered and kept in BOD chambers at temperatures of 42 and $45^{\circ} \mathrm{C}$ for 48,72 and 96 hours. After these periods, eight replications of 25 seeds were evaluated by germination test according to the methodology described below. The results were expressed as percentage of normal seedlings obtained at seven days after sowing.

Additionally, the seeds from each lot were subjected to the following tests:

Seed water content: was determined before and after each period of accelerated ageing. For this, the oven method at $105 \pm 3{ }^{\circ} \mathrm{C}$ for 24 hours was employed, using two subsamples of approximately $10 \mathrm{~g}$ per lot (BRASIL, 2009); the results were expressed on a wet basis as a percentage (\% wb).

The germination test was performed on eight subsamples of 25 seeds each, sown on germitest paper towel moistened with an amount of water equivalent to 2.7 times the weight of the dry paper (OLIVEIRA, 2009). Rolls were prepared, which were kept in a germinator at a temperature of $25^{\circ} \mathrm{C}$. Evaluations were done at seven 
and 12 days after sowing, with the values expressed as percentage (OLIVEIRA, 2009).

The first count for germination consisted of recording the number of normal seedlings obtained on the seventh day after the start of the germination test. These values were also expressed as percentage.

For the test of germination at low temperature, the method described by Dias and Alvarenga (1999) was used. Initially, the paper towel was moistened as described for the germination test and maintained at $20{ }^{\circ} \mathrm{C}$ for 24 hours. Seeding was then carried out using eight subsamples of 25 seeds each. The rolls were kept in a BOD chamber at $20{ }^{\circ} \mathrm{C}$. A single count was taken at 12 days after sowing, as established for the germination test by Oliveira (2009), considering as normal those seedlings with a hypocotyl length of $3.5 \mathrm{~cm}$ or longer and having a fully developed main root accompanied by at least two secondary roots. The results were expressed as percentage.

The cold test was carried out using a moistened paper towel as described for the germination test, but kept at $10{ }^{\circ} \mathrm{C}$ for the 24 hours before the test. After sowing on paper towels, $40 \mathrm{~mL}$ of soil was spread over the seeds to form a uniform layer. Rolls were prepared, which were packed into transparent plastic bags and kept at $10{ }^{\circ} \mathrm{C}$ in a BOD incubator for 7 days. The rolls were then removed from the plastic bags and transferred to a germinator at $25{ }^{\circ} \mathrm{C}$ where they remained for another five days. At the end of this period, a count was made of the number of normal seedlings using the same criteria as used in the germination at low temperature. The results were expressed as a percentage.

The seedling emergence test was conducted in a greenhouse using plastic trays containing a mixture of soil and washed and sterilised sand in a 2:1 ratio and initially moistened to $60 \%$ of its maximum holding capacity, according to Brasil (2009). Four subsamples of 50 seeds each were distributed in furrows $2 \mathrm{~cm}$ deep and spaced $5 \mathrm{~cm}$ apart. Irrigation was carried out when necessary. Daily counts were taken, until the twelfth day after seeding, of the number of seedlings which had cotyledons exposed above soil level in order to obtain the percentage of emerged seedlings.

The speed of seedling emergence (SE), expressed in days, and the seedling emergence speed index (SEI) were carried out together with the test for seedling emergence following the methodology described by Nakagawa (1999). Counts were taken daily from the day that saw the first emerged seedlings until the twelfth day after sowing. The SE (days) and the SEI were calculated according to Nakagawa (1999).
The hypocotyl length was determined with the aid of a ruler graduated in millimetres, the hypocotyl being measured from the base of the seedling to the point of insertion of the cotyledons, the results being expressed in $\mathrm{cm}$ seedling ${ }^{-1}$.

Seedling dry mass was determined by weighing the seedlings on a balance accurate to $0.001 \mathrm{~g}$ after drying them in a forced-air circulation oven set to a temperature of $60+2{ }^{\circ} \mathrm{C}$, until a constant weight was obtained. Results were expressed in $\mathrm{g}$ seedling ${ }^{-1}$.

The experimental design used was completely randomised with four replications. Data underwent variance analysis (ANOVA) in a $2 \times 3$ factorial scheme [ 2 temperatures $\left(42\right.$ and $45{ }^{\circ} \mathrm{C}$ ) $\mathrm{x} 3$ ageing periods (48, 72 and 96 hours)]. Data as percentages were tested for both normality of the residuals and homoscedasticity of the variances, which indicated that there was no need for transformation. In order to compare the mean scores for each test the Tukey test at 5\% probability was employed. The Pearson simple correlation coefficient (r) was also calculated for the results of the accelerated-ageing test against the other tests. The significance of the values for " $r$ " was determined by the t-test at 1 and $5 \%$ probability. Data processing was carried out using the SAS software (DELWICHE; SLAUGHTER, 2003).

\section{RESULTS AND DISCUSSION}

In Table 1 can be found the results for the tests of germination, first count, low-temperature germination, cold, soil emergence, speed of emergence, speed emergence index, and length of hypocotyl for the four lots of Jatropha seed. There was no difference in germination for the four lots, both at the first count and at final germination. Although the first count germination test is considered indicative of vigour, it is known that a reduction in the speed of germination is not included in the initial events of the process of deterioration according to the sequence proposed by Delouche and Baskin (1973). In general, this test does not allow the detection of small differences in vigour between seed lots (NAKAGAWA, 2009). Also it was not possible with the cold test to detect significant differences in the physiological quality of the lots.

Lot C, with germination of $82 \%$, did not demonstrate good performance in the tests of soil emergence, speed of emergence index, length of hypocotyl, seedling dry weight and low-temperature germination (Table 1). According to Marcos Filho (1999) this is one of the reasons for evaluating seed vigour before commercialising the seeds, because often lots showing high germination in the laboratory may exhibit inferior behaviour under field conditions. 
The germination at low temperature test showed Lot $\mathrm{C}$ to be inferior in relation to the other lots, which was also seen in the results of the percentage and speed index of seedling emergence in the soil, although in the tests for emergence and the emergence speed index this lot (C) did not differ significantly from lots A and D (Table 1). It is worth pointing out that seedling emergence is an important reference when comparing the efficiency of the vigour tests for evaluation of the physiological quality of the seeds (MARCOS FILHO, 2009).
For accelerated ageing test (Table 2), in general, there was a reduction in germination after ageing with increased exposure time. This result was expected as deterioration becomes more intense with the increase in the time of exposure to the adverse conditions of the test, with marked decreases occurring at a temperature of $45{ }^{\circ} \mathrm{C}$. As for the temperature of $42{ }^{\circ} \mathrm{C}$, the highest values of germination after ageing were observed for the period of 48 hours and the lowest values for the periods of 72 and 96 hours, which usually did not differ. It can

Table 1 - Mean values obtained in the tests of germination (\% G), first count (FC), germination at low temperature (GLT); cold test (CT); emergence in 2:1 soil (EM); speed of emergence (SE); speed of emergence index (SEI); length of hypocotyl (LH) and seedling dry matter (SDM) in four seed lots of Jatropha. Viçosa, Minas Gerais, 2013

\begin{tabular}{|c|c|c|c|c|c|}
\hline \multirow{3}{*}{ Lot } & \multicolumn{5}{|c|}{ Test } \\
\hline & $\mathrm{G}$ & FC & GLT & $\mathrm{CT}$ & EM \\
\hline & \multicolumn{5}{|c|}{ 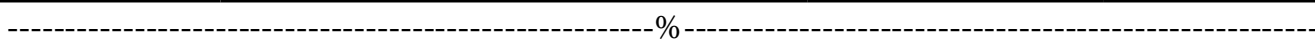 } \\
\hline A & $83 \mathrm{a}$ & $75 \mathrm{a}$ & $43 \mathrm{a}$ & $68 \mathrm{a}$ & $81 \mathrm{ab}$ \\
\hline B & $91 \mathrm{a}$ & $84 \mathrm{a}$ & 46 a & $73 \mathrm{a}$ & 94 a \\
\hline $\mathrm{C}$ & $82 \mathrm{a}$ & $78 \mathrm{a}$ & $9 \mathrm{~b}$ & $65 \mathrm{a}$ & $73 \mathrm{~b}$ \\
\hline $\mathrm{D}$ & $90 \mathrm{a}$ & $84 \mathrm{a}$ & $48 \mathrm{a}$ & $68 \mathrm{a}$ & $88 \mathrm{ab}$ \\
\hline \multirow[t]{2}{*}{$\mathrm{CV}(\%)$} & 6.93 & 5.88 & 21.22 & 6.41 & 8.96 \\
\hline & \multicolumn{5}{|c|}{ Test } \\
\hline \multirow[t]{2}{*}{ Lot } & $\mathrm{SE}$ & SEI & $\mathrm{LH}$ & \multicolumn{2}{|c|}{ SDM } \\
\hline & Days & seedlings day ${ }^{-1}$ & $\mathrm{~cm}$ seedling ${ }^{-1}$ & \multicolumn{2}{|c|}{ g seedling $^{-1}$} \\
\hline A & $12.13 \mathrm{ab}$ & $1.68 \mathrm{ab}$ & $11.04 \mathrm{~b}$ & \multicolumn{2}{|c|}{$0.41 \mathrm{~b}$} \\
\hline B & $11.72 \mathrm{~b}$ & $2.02 \mathrm{a}$ & $12.29 \mathrm{a}$ & \multicolumn{2}{|c|}{$0.45 \mathrm{a}$} \\
\hline $\mathrm{C}$ & $12.33 \mathrm{a}$ & $1.49 \mathrm{~b}$ & $10.69 \mathrm{~b}$ & \multicolumn{2}{|c|}{$0.38 \mathrm{c}$} \\
\hline $\mathrm{D}$ & $12.31 \mathrm{a}$ & $1.80 \mathrm{ab}$ & $11.86 \mathrm{a}$ & \multicolumn{2}{|c|}{$0.41 \mathrm{~b}$} \\
\hline $\mathrm{CV}(\%)$ & 1.99 & 9.51 & 3.2 & \multicolumn{2}{|c|}{3.49} \\
\hline
\end{tabular}

* Mean values followed by the same lowercase letter in a column do not differ between themselves by the Tukey test at $5 \%$ significance

Table 2 - Mean values for germination obtained after exposure to different temperatures and times for the accelerated ageing test of four seed lots of Jatropha. Viçosa, Minas Gerais, 2013

\begin{tabular}{|c|c|c|c|c|c|c|}
\hline \multirow{2}{*}{ Lot } & \multicolumn{3}{|c|}{ 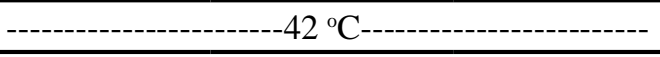 } & \multicolumn{3}{|c|}{ 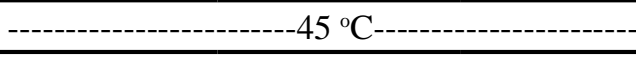 } \\
\hline & $48 \mathrm{~h}$ & $72 \mathrm{~h}$ & $96 \mathrm{~h}$ & $48 \mathrm{~h}$ & $72 \mathrm{~h}$ & $96 \mathrm{~h}$ \\
\hline A & $74 \mathrm{Aa}$ & $62 \mathrm{Aab}$ & $52 \mathrm{ABb}$ & $67 \mathrm{Aa}$ & $58 \mathrm{Aa}$ & $42 \mathrm{Ab}$ \\
\hline B & $72 \mathrm{Aa}$ & $59 \mathrm{ABb}$ & $54 \mathrm{Ab}$ & $69 \mathrm{Aa}$ & $62 \mathrm{Aa}$ & $39 \mathrm{Ab}$ \\
\hline $\mathrm{C}$ & $58 \mathrm{Ba}$ & $49 \mathrm{Bab}$ & $40 \mathrm{Bb}$ & $54 \mathrm{Ba}$ & $45 \mathrm{Bab}$ & $34 \mathrm{Ab}$ \\
\hline D & $74 \mathrm{Aa}$ & $53 \mathrm{ABb}$ & $46 \mathrm{ABb}$ & $68 \mathrm{Aa}$ & $60 \mathrm{Aa}$ & $38 \mathrm{Ab}$ \\
\hline$\overline{\mathrm{CV}(\%)}$ & \multicolumn{6}{|c|}{5.69} \\
\hline
\end{tabular}

* Mean values followed by the same uppercase letter in a column do not differ between themselves by the Tukey test at $5 \%$ significance; $*$ Mean values followed by the same lowercase letter on a line for each temperature, do not differ between themselves by the Tukey test at $5 \%$ significance 
be seen that at the temperature of $45^{\circ} \mathrm{C}$, there were no differences for the periods of 48 and 72 hours, which both yielded results whose values were greater than those for 96 hours, a condition that was drastic for the seeds, and which did not allow the classification of the lots by vigour.

According to Pereira, Martins Filho and Laviola (2012), the temperature of $45^{\circ} \mathrm{C}$ was also the most limiting for stratifying the lots of Jatropha seeds, preventing their classification by level of vigour due to the severe deterioration of the seeds.

At both of the temperatures and at the exposure times used, the seeds of lot $\mathrm{C}$ showed the worst performance (Table 2). Thus, using the accelerated ageing test, it was possible to stratify the lots by level of vigour for all combinations of temperature and time of exposure except at $45{ }^{\circ} \mathrm{C}$ for 96 hours, with lots $\mathrm{A}$, $\mathrm{B}$ and $\mathrm{D}$ being classified as more vigorous, showing no difference between themselves, and Lot $\mathrm{C}$ as the least vigorous (Table 2 ).

In Table 2, it can be seen that for the period of 48 hours at both temperatures $\left(42\right.$ and $45^{\circ} \mathrm{C}$ ) separation of the seed lots of Jatropha by vigour was possible. Similar behaviour was observed for the remaining periods, the only exception being that of 96 hours at $45^{\circ} \mathrm{C}$, which was drastic for the Jatropha seeds, preventing separation of the lots as previously mentioned. Mendes et al. (2010), working with the accelerated ageing test on castor bean seeds, found that combinations of the periods of 48,72 and 96 hours with a temperature of $45^{\circ} \mathrm{C}$ were drastic for the seeds, since these combinations of temperature and times of exposure contributed to accelerate the process of deterioration.

Accelerated ageing at $45^{\circ} \mathrm{C}$ for 96 hours therefore, led to excessive deterioration of the Jatropha seeds from all lots (Table 2), making it difficult to identify their actual level of vigour, especially in lot $C$, which was characterised as having the worst vigour in the tests of soil emergence and germination at low temperature (Table 1).
In seeds of the castor bean, Mendes et al. (2010) found that the accelerated ageing test at $41{ }^{\circ} \mathrm{C}$ and $100 \% \mathrm{RH}$ for 72 hours, allowed for the separation of lots by different levels of vigour, corresponding to the classification of the lots obtained in the other tests of vigour employed. Similar results were also observed by Freitas et al. (2004), who were able to stratify lots of castor beans, using a temperature of $42{ }^{\circ} \mathrm{C}$ for 72 hours. On the other hand, Rocha et al. (2007) and Lopes et al. (2008) found that the accelerated ageing test at 40 and $42{ }^{\circ} \mathrm{C}$ and $100 \% \mathrm{RH}$ for 72 hours caused the death of the castor bean seeds, a fact that did not occur when a relative humidity of $76 \%$ was used. Braz et al. (2008), using both the traditional and modified methods (saline solution) in sunflower seeds, found a significant reduction in seed viability after 72 hours of exposure at $42{ }^{\circ} \mathrm{C}$ using the traditional method, these results not being observed when the modified method was used.

In general, greater fungal contamination was observed in the tests conducted at $45{ }^{\circ} \mathrm{C}$ which can be evidenced by the lower values obtained at this temperature. Mendes et al. (2010) report that with seeds of the castor bean, for the accelerated ageing test at $45^{\circ} \mathrm{C}$ and all the periods tested, lower germination values were observed compared to a temperature of $41{ }^{\circ} \mathrm{C}$, indicating that the former temperature was more drastic to the seeds. The association of accelerated ageing at $45{ }^{\circ} \mathrm{C}$ with a greater exposure period (96 hours) caused excessive deterioration of the castor seeds, making it difficult to identify the actual level of vigour of the lots (MENDES et al., 2010), which was also observed in the present work with Jatropha seeds (Table 2). Under these conditions, there was a higher occurrence of seeds and seedlings infected by microorganisms.

The seed water content determined both before and after exposure to different periods of accelerated ageing is shown in Table 3 . The initial values of the water content of the four seed lots were similar, ranging from 8.45 to 8.90 . This small variation in the initial moisture

Table 3 - Water content (\% WC) for four seed lots of Jatropha before and after exposure to the accelerated ageing test (AA) at two temperatures and three periods of exposure. Viçosa, Minas Gerais, 2013

\begin{tabular}{lccccccc}
\hline \multirow{2}{*}{ Lot } & \multirow{2}{*}{ Before AA } & \multicolumn{3}{c}{ After AA 42 ${ }^{\circ} \mathrm{C}$} & \multicolumn{3}{c}{ After AA 45 ${ }^{\circ} \mathrm{C}$} \\
\cline { 3 - 8 } & & $48 \mathrm{~h}$ & $72 \mathrm{~h}$ & $96 \mathrm{~h}$ & $48 \mathrm{~h}$ & $72 \mathrm{~h}$ & $96 \mathrm{~h}$ \\
\hline $\mathrm{A}$ & 8.45 & 18.20 & 18.20 & 19.20 & 16.00 & 16.35 & 18.30 \\
$\mathrm{~B}$ & 8.55 & 14.30 & 17.20 & 17.40 & 15.55 & 16.30 & 17.45 \\
$\mathrm{C}$ & 8.90 & 16.25 & 19.15 & 21.95 & 17.65 & 18.10 & 19.30 \\
$\mathrm{D}$ & 8.85 & 15.70 & 16.90 & 18.50 & 15.15 & 16.60 & 17.95 \\
\hline
\end{tabular}


content of the seed lots constitutes an important factor for the standardisation of evaluations and obtaining consistent results (LOEFFLER; TEKRONY; EGLI, 1988; MARCOS FILHO, 1999).

When conducting the accelerated ageing test, seed samples with a similar moisture content should be used whenever possible, because when values are very different there is a marked variation in the rate of water absorption by the seeds during the test, resulting in differences in the intensity of deterioration. Differences of 1 to 2 percentage points in the initial moisture content of the seeds from different lots are considered tolerable. On the other hand, one of the leading indicators of uniformity for the condition of ageing is the moisture content of the seeds at the end of the test; variations of 3 to 4 percentage points between samples are tolerable (MARCOS FILHO, 1999).

When the seeds present very different values for initial moisture, there may be a sharp variation in the speed of water absorption during the accelerated-ageing test which may result in differences in the intensity of deterioration of the lots. It is important to note that the more moistened seeds are generally more sensitive to the conditions of the accelerated-ageing test. According to Bewley and Black (1994), the relative humidity of the air is highly related to the water content of the seeds, which in turn governs the occurrence of various metabolic processes in the seeds, while the temperature affects the speed with which these biochemical processes occur and interfere indirectly with the water content of the seeds.

The seed moisture content after each period of accelerated ageing at 42 and $45^{\circ} \mathrm{C}$ (Table 3), increased with the increase in exposure time of the seeds to ageing, a result that was already expected. In all the combinations of time and temperature, it was observed that the seed lots of Jatropha presented a moisture content at the end of the test which was within the tolerable limits reported by Marcos Filho (1999), indicating a uniformity in the conditions of the test.

The Pearson linear correlation coefficients between the accelerated ageing data and those obtained in the other tests are listed in Table 4. Positive correlations were observed between the results of accelerated ageing at 42 and $45^{\circ} \mathrm{C}$ and those of germination at low temperature for all the ageing periods, except for the combination of $42{ }^{\circ} \mathrm{C}$ for 72 hours. It is also important to point out the positive correlation between the accelerated ageing test and the test of seedling emergence in the soil, both at $42^{\circ} \mathrm{C}$ and at $45^{\circ} \mathrm{C}$, for the ageing periods of 48 and 96 hours and 48 and 72 hours respectively (Table 4).

Table 4 - Pearson correlation coefficients between the data from the accelerated ageing test in Jatropha seeds and that of germination (\% G), first count (FC), germination at low temperature (GLT), cold test (CT), emergence in the soil (EM), speed of emergence (SE), speed of emergence index (SEI), length of hypocotyl (LH) and seedling dry matter (SDM). Viçosa, Minas Gerais, 2013

\begin{tabular}{|c|c|c|c|c|c|c|}
\hline \multirow{3}{*}{$\begin{array}{c}\text { Temperature } \\
\left({ }^{\circ} \mathrm{C}\right)\end{array}$} & \multirow{3}{*}{ Time (hours) } & \multicolumn{5}{|c|}{ Test } \\
\hline & & G & $\mathrm{FC}$ & GLT & $\mathrm{CT}$ & EM \\
\hline & & \multicolumn{5}{|c|}{ 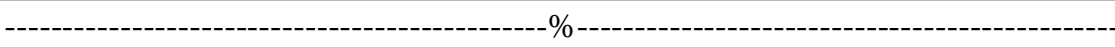 } \\
\hline \multirow{3}{*}{42} & 48 & 0.22 & 0.12 & $0.62 * *$ & 0.41 & $0.56^{*}$ \\
\hline & 72 & -0.05 & -0.14 & 0.34 & 0.11 & 0.22 \\
\hline & 96 & 0.24 & 0.13 & $0.73 * *$ & $0.53 *$ & $0.62 * *$ \\
\hline \multirow{3}{*}{45} & 48 & 0.35 & 0.23 & $0.86 * *$ & 0.45 & $0.63 * *$ \\
\hline & 72 & 0.47 & 0.40 & $0.89 * *$ & 0.48 & $0.69 * *$ \\
\hline & 96 & 0.16 & -0.14 & $0.67 * *$ & 0.30 & 0.42 \\
\hline \multirow{3}{*}{$\begin{array}{c}\text { Temperature } \\
\left({ }^{\circ} \mathrm{C}\right)\end{array}$} & \multirow{3}{*}{ Time (hours) } & \multicolumn{5}{|c|}{ Test } \\
\hline & & SE & SEI & LH & \multicolumn{2}{|c|}{ SDM } \\
\hline & & days & seedlings.day $^{-1}$ & $\mathrm{~cm}$ seedling $^{-1}$ & \multicolumn{2}{|c|}{ g.seedling ${ }^{-1}$} \\
\hline \multirow{3}{*}{42} & 48 & -0.36 & $0.56^{*}$ & $0.50 *$ & \multicolumn{2}{|c|}{0.50} \\
\hline & 72 & -0.14 & 0.22 & 0.07 & \multicolumn{2}{|c|}{0.19} \\
\hline & 96 & -0.55 & $0.66 * *$ & $0.50 *$ & \multicolumn{2}{|c|}{$0.70 * *$} \\
\hline \multirow{3}{*}{45} & 48 & -0.49 & $0.65 * *$ & $0.64 * *$ & \multicolumn{2}{|c|}{$0.74 * *$} \\
\hline & 72 & -0.46 & $0.70 * *$ & $0.70 * *$ & \multicolumn{2}{|c|}{$0.76 * *$} \\
\hline & 96 & -0.23 & 0.41 & 0.29 & \multicolumn{2}{|c|}{$0.50 *$} \\
\hline
\end{tabular}

**Significant at $1 \%$ probability; $*$ Significant at $5 \%$ probability 
The accelerated-ageing test therefore proved to be efficient in evaluating the vigour of Jatropha seeds, allowing the classification of lots by level of vigour in a similar way to the germination at low temperature and seedling emergence tests (Table 1). Since the shortest time for conducting this test is an important aspect for speed in obtaining results, using 42 or $45{ }^{\circ} \mathrm{C}$ for 48 hours is recommended.

In the accelerated ageing test for seeds of major crops, the most used temperatures are 41 or $42{ }^{\circ} \mathrm{C}$ for a period of time which varies depending on the species. However, according to Marcos Filho (1999), some more recent studies have indicated the use of a temperature of $45^{\circ} \mathrm{C}$, with an aim to reducing testing time. Results obtained by Bittencourt and Vieira (2006), found that in maize seeds the combination of a high temperature $\left(45^{\circ} \mathrm{C}\right)$ and 72 hours, enabled the efficient separation of seed lots of superior and inferior quality, regardless of genotype. Generally when the accelerated ageing test is conducted at higher temperatures, in this case at $45^{\circ} \mathrm{C}$, the incidence of microorganisms is higher, which can make the evaluation difficult or interfere with the results, especially for lots with less vigour or which are contaminated by fungi. This was noted in the present work. Taking this aspect into account, a temperature of $42{ }^{\circ} \mathrm{C}$ would be the most appropriate.

\section{CONCLUSIONS}

1. The accelerated ageing test is effective in the classification of seed lots of Jatropha as to vigour;

2. The best combination of time and temperature when conducting the test is 42 or $45^{\circ} \mathrm{C}$ for 48 hours, resulting in a classification of lots similar to that obtained in the test of seedling emergence in the soil.

\section{ACKNOWLEDGEMENTS}

The authors wish to thank CNPq and FAPEMIG for their financial support and for the award of a $\mathrm{PhD}$ scholarship to the first author.

\section{REFERENCES}

BEWLEY, D. D.; BLACK, M. Seeds: Physiology of development and germination. New York: Plenum Press, 1994. 445 p.

BITTENCOURT, S. R. M.; VIEIRA, R. D. Temperatura e período de exposição de sementes de milho no teste de envelhecimento acelerado. Revista Brasileira de Sementes, v. 28, n. 3, p. 161-168, 2006.
BRAGA JUNIOR, J. M. et al. Teste de envelhecimento acelerado em sementes de mamona cultivar BRS - Energia. Revista Eletrônica de Biologia, v. 4, n. 1, p. 88-111, 2011.

BRASIL. Ministério da Agricultura e Reforma Agrária. Regras para Análises de Sementes. CLAV/DNDV/SNDA/ MA, 2009. 365 p.

BRAZ, M. R. S. et al. Testes de envelhecimento acelerado e deterioração controlada na avaliação do vigor de aquênios de girassol. Ciência Rural, v. 38, n. 7, p. 1857-1863, 2008.

DELWICHE, L. D.; SLAUGHTER, S. J. The Little SAS Book: A Primer. Cary: SAS Institute, 2003. 268 p.

DELOUCHE, J.C.; BASKIN, C. C. Accelerated aging techniques for predincting the relative storability of seed lots. Seed Science and Technology, v. 1, n. 2, p. 427-452, 1973.

DIAS, D. C. F. S.; ALVARENGA, E. M. Teste de germinação a baixa temperatura. In: KRZYZANOWSKI, F. C.; VIEIRA, R. D.; FRANÇA NETO, J. B. Vigor de sementes: conceitos e testes. Londrina: ABRATES, 1999. cap. 7, p. 1-3.

FREITAS, R. A. et al. Testes fisiológicos e bioquímicos na estimativa do potencial de armazenamento de sementes de algodão. Revista Brasileira de Sementes, v. 26, n. 1, p. 84-91, 2004.

LOEFFLER, T. M.; TEKRONY, D. M.; EGLI, D. B. The bulk conductivity test as an indicador of soybean seed quality. Journal of Seed Techonology, v. 12, n. 1, p. 37-53, 1988.

LOPES, F. F. de M. et al. Crescimento inicial de genótipos de mamoneira com sementes submetidas ao envelhecimento acelerado. Revista Brasileira de Oleaginosas e Fibrosas, v. 12, n. 2, p. 69-79, 2008.

MARCOS FILHO, J. Teste de envelhecimento acelerado. In: KRZYZANOWSKI, F. C.; VIEIRA, R. D.; FRANÇA NETO, J. B. Vigor de sementes: conceitos e testes. Londrina: ABRATES, 1999. cap.1, p. 1-21.

MENDES, R. C. et al. Testes de vigor para avaliação do potencial fisiológico de sementes de mamona (Ricinus communis L.). Ciência e Agrotecnologia, v. 34, n. 1, p. 114-120, 2010.

NAKAGAWA, J. Testes de vigor baseados no desempenho das plântulas. In: KRZYZANOWSKI, F. C.; VIEIRA, R. D.; FRANÇA-NETO, J. B. Vigor de sementes: conceitos e testes. Londrina: ABRATES, 1999. p. 1-21.

OLIVEIRA, G. L. Testes para avaliação da qualidade fisiológica de sementes de pinhão manso (Jatropha curcas L.). 2009. 60 f. Dissertação (Mestrado em Agronomia/Fitotecnia) - Centro de Ciências Agrárias, Universidade Federal de Viçosa, Viçosa, 2009.

PEREIRA, M. D. Alterações fisiológicas, bioquímicas e qualidade de óleo de $\boldsymbol{J}$. curcas L. durante o armazenamento. 2011. 94 f. Tese (Doutorado em Agronomia/Fitotecnia) - Centro de Ciências Agrárias, Universidade Federal de Viçosa, Viçosa, 2011.

PEREIRA, M. D.; MARTINS FILHO, S.; LAVIOLA, B. G. Envelhecimento acelerado de sementes de pinhão manso. Revista Pesquisa Agropecuária Tropical, v. 42, n. 1, p. 119123, 2012. 
ROCHA, M. S. et al. Teste de envelhecimento acelerado em sementes de mamona cultivar BRS Energia. In: CONGRESSO BRASILEIRO DE PLANTAS OLEAGINOSAS, ÓLEOS, GORDURAS E BIODIESEL, 2007, Varginha. Anais... Varginha: Universidade Federal de Lavras, 2007. p. 14211431.

ROSSETO, C. A. V.; LIMA, T. M.; GUIMARÃES, E. C. Envelhecimento acelerado e deterioração controlada em sementes de amendoim. Pesquisa Agropecuária Brasileira, v. 39 , n. 8 , p. $795-801.2004$.
ROSSETTO, C. A. V.; ARAúJO, A. E. S.; LiMA, T. M. Avaliação da aplicação de fungicida às sementes de amendoim antes do envelhecimento acelerado. Revista Brasileira de Sementes, v. 25, n. 1, p. 101-107, 2003.

SILVA L. J. et al. Relationship between fruit maturation stage and physiological quality of physic nut (Jatropha curcas L.) seeds. Ciência e Agrotecnologia, v. 36, n. 1, p. 39-44, 2012.

ZONTA, J. B. et al. Diferentes tipos de secagem: efeitos na qualidade fisiológica de sementes de pinhão manso. Revista Brasileira de Sementes, v. 33, n. 4, p. 721-31, 2011. 